\title{
Comparison Drying Behavior of Seaweed in Solar, Sun and Oven Tray Dryers
}

\author{
Suherman Suherman*, Moh. Djaeni, Andri C. Kumoro, Rizky A. Prabowo, Sri Rahayu and Sufrotun Khasanah \\ Departement of Chemical Engineering, Faculty of Engineering, Diponegoro University, J1. Prof. Soedarto, SH Tembalang, Semarang, \\ Indonesia 50239
}

\begin{abstract}
The main objective of this study is to analyze and compare the drying behavior of seawage experimentally in solar dryer, sun dryer and oven dryer. Seaweeds with moisture content of $70 \%$ have been cleansed of impurities attached and washed with fresh water. The solar dryer tool is made of glass and iron shaped dryer and box, where the solar collector is made of black painted iron plate. The results showed that the air temperature in solar dyrer was higher than the ambient. The air humidity relative in the solar dryer is lower than the ambient. Drying seaweed by solar dryer method can dry the material up to $12.2 \%$ water content within 16 hours, and faster than sun dryer method. Energy utilization per kg of material for solar dryer, sun dryer and oven dryer is $1493 \mathrm{~kJ} / \mathrm{kg}, 1338 \mathrm{~kJ} / \mathrm{kg}$, and $1620 \mathrm{~kJ} / \mathrm{kg}$, respectively. The quality of the product by the solar dryer method produces the best dried seaweed products in terms of color, aroma and contaminants in the product
\end{abstract}

\section{Introduction}

Drying is the transfer of heat and water vapor simultaneously, which requires heat energy to evaporate the water content removed from the surface of the material, which is dried by the media which is usually a hot dryer. One of the materials can be dried seaweed because it has a high water content. Seaweed is classified as low-level plant, does not have roots, stems and true leaves, but only resemble rods called thallus, growing in the wild to attach themselves to rocks, mud, sand, rocks and other hard objects. Indonesia is one country with a great potential sea grass, where Indonesia has approximately 555 species of 8642 species of seaweed found in the world (Bosse, 1899). Although it has great potential but the seaweed development program potential is still very low because of the production is still using the conventional drying process is drying with the help of sunlight. This drying is done 2-3 days depending on weather conditions. Drying method It also causes the product to be contaminated with dirt from the outside air. Drying method is one of the potential development program seaweed one using solar drying method. Solar drying is a method or way of drying a food using solar radiation energy, this method is the most inexpensive and easily as using direct heat from the sun. Solar drying is assisted simple tools and a drying chamber as a place. Solar drying is shaped like a closed room with transparent walls. With the closing of this tool, it can avoid the contaminants from the surrounding environment. With the closing of this tool, it can avoid the contaminants from the surrounding environment. At the bottom will be placed a heat collector rectangular painted black. Drying seaweed using Solar drying shows that the mathematical model of the drying curve is a variable measured during the drying process and shows the effectiveness of the drying method (Fudholi et al., 2013).Solar drying method is expected to improve the quality of dried seaweed.

The research objective of drying seaweed with methods of solar drying is to determine the profile of the temperature and humidity, know the profile of the curve of drying the seaweed with a method of solar dryers, electric dryer and sun dryer, as well as analyzes of economic deals with the analysis of the energy efficiency of products produced from three various methods namely solar dryers sun electric dryer and dryer.

\section{Materials and Methods}

\subsection{Materials}

The method used in this seaweed drying are solar drying method. Preliminary research needs to be conducted to determine the initial water content in the ingredients seaweed. Initial preparation of washing the seaweed. Then the fresh seaweed was cut with dimensions of $3 \mathrm{~cm}$ $\mathrm{x} 0.5 \mathrm{~cm} \times 0.2 \mathrm{~cm}$. Once cut to the desired dimensions, materials incorporated into solar dryers dryers.

Corresponding author: suherman.mz@che.undip.ac.id 


\subsection{Drying Equipment}
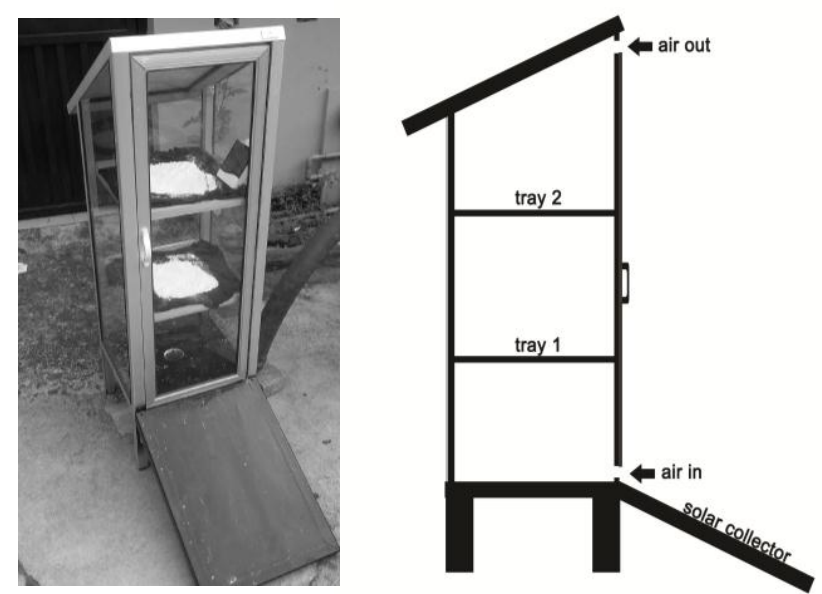

Fig. 1. Solar Tray Dryer

The prototype of Solar dryer has a dimension 40x40×150 $\mathrm{cm}$. The materials used in the manufacture of the prototype of Solar dryer has some special characteristics. First, choose materials affordable to expectations in its application were able to save cost from the price. Second, lightweight materials to facilitate the operation of the device itself, for example if you want to be moved or taken to another place. Third, the selected material has the properties of heat collectors. With these properties then the heat will accumulate inside the tool so that it can speed up the drying process. This tool is also made of a material that is not easily broken, broken or porous so as to reduce the risk of damage and loss. Aluminum is used as the framework is a good conductor of heat, light and affordable.

Drier is made in the form of shelves in order to have a drying capacity of the lot. The roof is sloped so that when it rains, the water can drip down easily so it will not wet the dried material. In addition, the slope of the roof is water vapor attached to the roof produced during drying is expected to easily flow out through the roof and walls so that the dried material will be protected from water vapor that condenses droplets. On the roof there is a hole as a water vapor expenditure, the purpose is that water vapor formed during the drying process may soon be out of the appliance. Solar dryer is shaped like a closed room with transparent walls. With the closing of this tool, it can avoid any contamination from the surrounding environment. At the bottom of the tool will be placed a heat collector rectangular painted black.

\section{Results and Discussion}

\subsection{Profile Temperature, Humidity and Solar Radiation Average on Drying Solar Dryer}

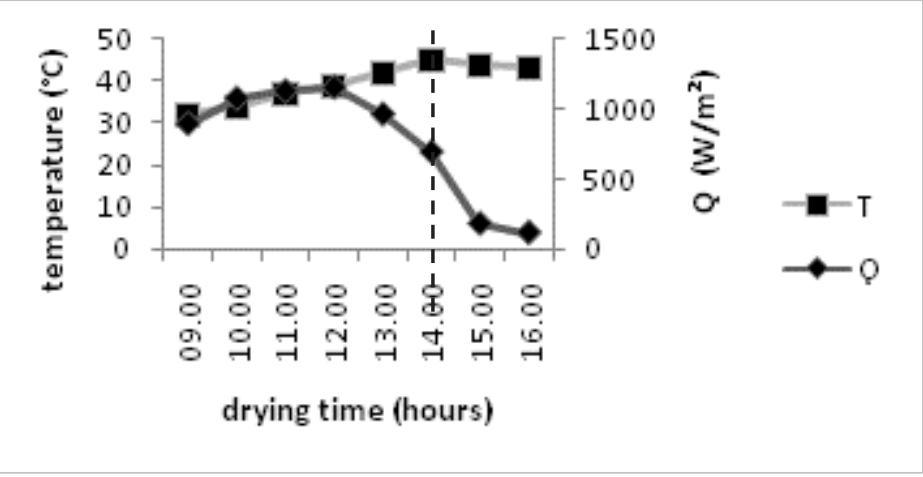

Fig. 2. The average solar temperature and radiation curve curve with the drying time of the solar drying method

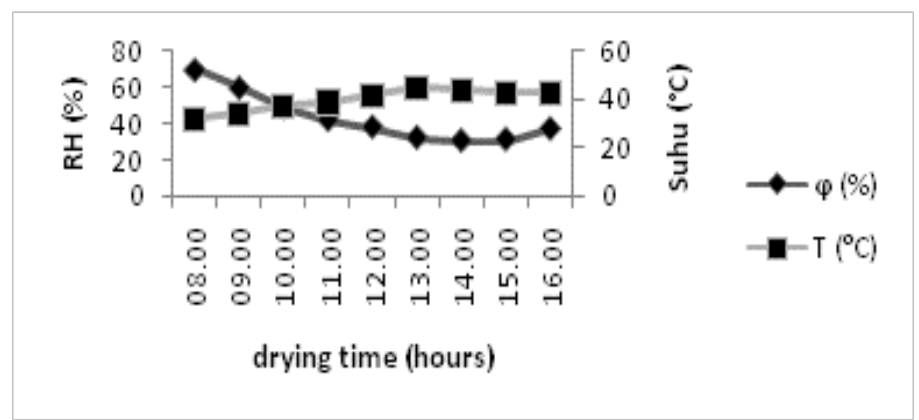

Fig. 3. Average temperature and humidity relation curve with drying method drying time

Based on Figure 3.1 shows that in times of high solar radiation, temperatures in the dryer will increase and vice versa when the solar radiation began to decrease the temperature in the dryer will be reduced, the solar dryers. Their thermal collectors will store heat so that the current decline in solar radiation were not significant air temperature in the drier solar dryers remain high, the potential at the time of solar radiation maximum and the air temperature dryers are high is used to lower the water content of seaweed on the methods of solar drying.

In addition to the temperature and solar radiation, solar drying method is also affected by the humidity in the dryer, by drawing 3.2 it can be seen that when the solar radiation is low, the drying air temperature is low so the drier the air humidity is high. Air humidity will decrease with increasing solar radiation and drying air temperature, so that it can be concluded that the value of the air humidity is inversely proportional to the solar radiation and air temperature dryer (Yuwana, 2003). 


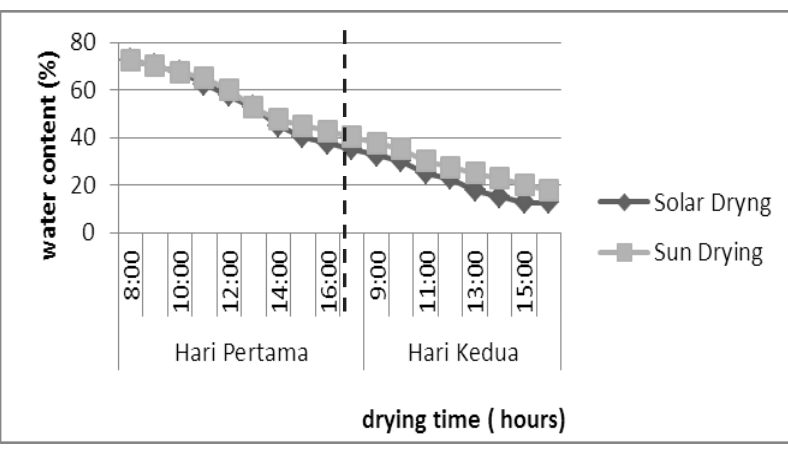

Fig. 4. Curve relation with the water content of the drying time of solar dryers and sun dryer metods

Drying with a solar dryer capable of lowering the water content of seaweed quickly than the sun dryer, because of differences in temperature dryer. Temperature in the collector is higher compared to the wild open. The temperature difference is due to drier solar dryers were able to raise outside air temperature average $130 \mathrm{C}$, in addition to the effects of angina open can increase the humidity in the environment dryers while in solar dryers shape of the instrument closed on several sides so as angina not significant in raising the humidity in dryer.

\subsection{Comparison of Drying Tray Dryer and Oven}

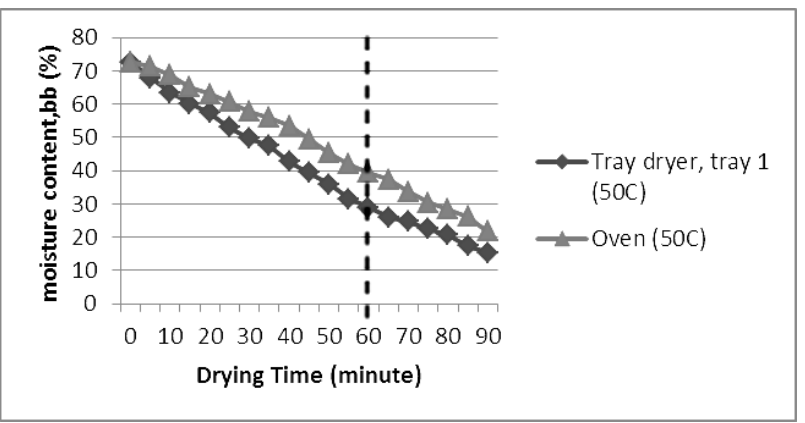

Fig. 5. Curve moisture content relation with electric dryer when drying method

Based on Figure 3.4 shows that a decline in the water content of seaweed is not significant spike at any given time.This drying using a tray dryer.Drying is able to reduce the water content of seaweed quickly than using the oven, is due to the direct contact with the seaweed, so the water will evaporate on the surface of the material.

\subsection{Analysis of Energy Efficiency Drying Seaweed}

\begin{tabular}{|c|c|c|c|c|}
\hline Mnalysis & $\begin{array}{c}\text { Solar } \\
\text { dryer/ } \\
400 \text { gram }\end{array}$ & $\begin{array}{c}\text { Sun Dryer } \\
\text { / 200 gram }\end{array}$ & \multicolumn{2}{|c|}{ Electric dryer (KJ) } \\
\cline { 3 - 5 } & 12,6 & 17,6 & $\begin{array}{c}\text { Tray dryer } \\
/ 200 \text { gram }\end{array}$ & $\begin{array}{c}\text { Oven / } 100 \\
\text { gram }\end{array}$ \\
\hline Water content & $597,8 \mathrm{kj}$ & $267,6 \mathrm{kj}$ & $297,98 \mathrm{kj}$ & 162,4 \\
\hline Energy & $9,5 \%$ & $9,1 \%$ & $4,3 \%$ & $3,7 \%$ \\
\hline $\begin{array}{c}\text { Efficiency of } \\
\text { drying }\end{array}$ & $27,7 \%$ & - & - & - \\
\hline $\begin{array}{c}\text { Efficiency of } \\
\text { solar collector }\end{array}$ & $27 \%$ & - & - & - \\
\hline $\begin{array}{c}\text { Efficiency of } \\
\text { drying* }\end{array}$ & $35 \%$ & - & - & - \\
\hline $\begin{array}{c}\text { Efficiency of } \\
\text { solar collector* }\end{array}$ & & & & \\
\hline
\end{tabular}

Fig. 6. Dryer Efficiency and Drying Time of Solar Drying Method

Based on Table 3.1 it can be seen that the solar dryer to produce dry seaweed with a water content of $12.6 \%$ smaller than the sun method dryer and electric dryer. Drying efficiency is directly proportional to the amount of heat that is utilized where the efficiency increases if the heat given are largely utilized to dry some more materials to achieve the desired moisture content. whereas in drier tray dryer with the amount of energy used is greater than the method of sun dryer but the value of the efficiency of drying is lower, it is because of the difference in temperature in the dryer, where the temperature in the dryer tray dryer is higher, should the heat generated can be utilized to drain more ingredients that will increase the drying efficiency.

The efficiency of the solar collector solar dryers method at $27.7 \%$ efficiency solar collector where the results showed a smaller value of research fudholi et al, 2013 at $27 \%$ and $35 \%$ this is because in this study, the design of solar dryers used tool is simple yet equipped with a heat supplier.

\section{Conclusion}

Air humidity will decrease with increasing solar radiation and air temperature dryers, drying seaweed solar dryers method can dry ingredients until the water content of $12.2 \%$ faster than the methods of sun dryer, drying energy analysis method for solar dryers that 597.8 $\mathrm{kJ} / 0$, 4kg material, sun dryer $267,6 \mathrm{kj} / 0,2 \mathrm{~kg}$ of material, the efficiency of solar dryers drying method, namely, sun dryer, respectively $9.5 \%, 9.1 \%$, where the value of solar dryers dryer efficiency is $27.7 \%$

\section{References}

1. B. M. A. Amer, M. A. Hossain, \& K. Gottschalk. Energy conversion and management, 51, 813-820. (2010).

2. W.L. Badger, and J.T. Banchero, Introduction to chemical Engineering. McGraw Hill, Kogakusha,Ltd, Tokyo. (1995).

3. Bono, A., Farm, Y. Y., Yasir, S. M., Arifin, B., \& Jasni, M. N. Production of fresh seaweed powder using spray drying technique. (2011). 
4. A.A. El-Sebaii, , and S.M. Shalaby., Renewable and Energy Reviews. 16. 37-43. (2012).

5. A. H. M. A. D. Fudholi, M. H.Ruslan, , M. Y. Othman, A. Zaharim, , \& K. Sopian, In Proceedings of the 6th WSEAS Int. Conf. on Renewable Energy Sources (RES'12) 36-41. (2012).

6. S.Gupta, , S.C ox, , \& N. Abu-Ghannam,. LWT-Food Science and Technology, 44, 1266-1272. (2011).

7. S. Hirao., Overseas Technical Cooperation Agency Goverment of Japan, 148 . (1971).

8. Juraev, E.T., and J.S, Akhatov. Study of MixedMode Forced Convection Solar Drier. Applied Solar Energy, 45,. 61-64. (2009).

9. Mc. Ketta. John.. Encyclopedia Chemical Process and Design. Marchell Dekker Inc., New York (1983)

10. N. S. Rathore Renewable and Energy Reviews, 16, 37-43. (2010).

11. A.Nonclercq, Food Sec, 1, 197-205. (2009).

12. A.Reyes,. Energy Conversion and management, 83, 241-248. (2014).

13. Yuwanadan Silvia Evanila. 2003. Application of YSD-UNIB12 Model Solar Dryer for Red Pepper, Mustrad and Cassava Leaf Drying. JurusanTeknologiPertanian.FakultasPertanian,,Unive rsitas Bengkulu. 